\title{
KAJIAN SIFAT FISIKA TANAH SUB DAS AIR BATANANG DAS SUMPUR KECAMATAN BATIPUH KABUPATEN TANAH DATAR
}

\author{
Yulnafatmawita, A mrizal Saidi, dan Al Asfhihani Elnita \\ Jurusan Tanah Fakultas Pertanian Unand
}

\begin{abstract}
Excessive utilization of natural resource by human being will affect the sustainability of agriculture, land and environment. This is due to degradation of soil physical properties in the area. A research about study of soil physical properties had been taken out in a sub-sub watershed Batanang of Sumpur watershed, Batipuh, Tanah Datar Regency, in West Sumatra. The research was conducted by surveying the area in 2006. Disturbed and undisturbed soil samples were taken in different land units. Then, soil samples were analysed at soil laboratory, Agriculture College, Andalas University Padang. The result showed that all of land units in this sub sub watersehed had the same soil texture class, that was fine clay. The bulk volume of the soil was higher in Mixed woodland unit than those in forest land units. Permeability value of the soil was higher at forest from all degrees of slope than that at mixed woodland, even though soil organic matter content of mixed woodland unit higher than that at forest with 25$45 \%$ slope.
\end{abstract}

Keywords: Sub watershed (DAS), forest, land unit, soil physical properties

\section{PENDAHULUAN}

Pemanfaatan sumberdaya alam secara berlebihan dan tidak sesuai dengan daya dukungnya akan mengakibatkan tekanan sangat berat terhadap lahan. Hal ini terjadi karena pengusahaan dan penggarapan lahan dilakukan di lerenglereng daerah aliran sungai (DAS) yang menitik-beratkan pada pola usahatani tanaman pangan. Selanjutnya, penggundulan hutan secara liar, pengolahan lahan tanpa memberikan tambahan input bagi peningkatan kesuburan tanah, serta tidak memperaktekkan kaedah-kaedah konservasi akan menimbulkan kerusakan lingkungan dan kemerosotan kualitas sumberdaya tanah, air, dan vegetasi. Hal tersebut dapat mengganggu keseimbangan ekosistem DAS yang pada gilirannya akan mengakibatkan kemerosotan peri kehidupan manusia yang tinggal dalam DAS tersebut (Haryanto et al., 1990).

Ditjen Tanaman Pangan (1984) menyatakan bahwa permasalahan yang timbul karena kesalahan pengelolaan sumberdaya alam dalam DAS ini antara lain yaitu :
1) Peningkatan bahaya erosi tanah

2) Peningkatan banjir pada musim hujan dan kekeringan pada musim kemarau

3) Pelumpuran waduk, sungai, dan saluran irigasi, dan

4) Pertambahan luas lahan kritis.

Pengelolaan sumberdaya alam bertujuan untuk mewujudkan kondisi optimal dari sumberdaya tanah, air, dan vegetasi yang meliputi empat hal pokok yakni; a) pengelolaan lahan melalui usaha konservasi tanah dalam arti luas; b) pengelolaan air melalui pengembangan sumberdaya air; c) pengelolaan vegetasi, khususnya pengelolaan hutan yang memiliki fungsi perlindungan terhadap tanah dan air; dan d) pembinaan kesadaran dan kemampuan manusia dalam penggunaan sumberdaya alam secara bijaksana, sehingga ikut berperan serta pada upaya pengelolaan DAS.

Pengelolaan DAS menyangkut kegiatan pengelolaan sumberdaya alam air, tanah, vegetasi, dan pengembangan sumberdaya manusia dengan mempertimbangkan aspek sosial, ekonomi dan kelembagaan di dalam dan di sekitar DAS. Tanah dan air merupakan dua sumber daya alam daerah aliran sungai yang utama 
serta peka dari berbagai kerusakan. Kerusakan itu bukan hanya terjadi oleh karena kehilangan unsur hara dan bahan organik dari daerah perakaran yang mengakibatkan kemerosotan kesuburan tanah, tetapi juga terungkapnya unsur hara yang beracun bagi tanaman (Syarbaini,1989). Kerusakan sumberdaya alam tanah di daerah tropika paling utama disebabkan oleh kaena pengaruh erosi.

Besar kecilnya erosi dari suatu lahan sangat ditentukan oleh kondisi fisika tanah itu sendiri. Tanah dengan sifat fisika yang jelek, khususnya stabilitas aggregate tanah, akan mudah mengalami erosi dan degradasi lahan. Hal ini disebabkan karena tanah yang aggregatnya tidak stabil akan mudah hancur oleh pukulan butir hujan dan partikel halus seperti liat akan tersuspensi dalam air, sedangkan partikel debu akan memasuki/menyumbat pori tanah sehingga laju infiltrasi menurun dan aliran permukaan meningkat pada daerah lereng. Pada daerah datar, kondisi demikian akan membuat genangan dan akan terbentuk kerak tanah setelah tanah kering. Kerak tanah ini walaupun tipis tetapi menyebabkan terhambatnya aerase tanah dan berkurangnya laju infiltrasi.

Stabilitas aggregate tanah sangat tergantung pada agen pengikat butir dan penstabilannya, di samping tekstur tanah. Salah satu agen pengikat dan penstabilan aggregate tanah yaitu bahan organik. Bahan organik bukan saja mampu menciptakan struktur tanah yang remah serta seimbang antara pori mikro dan makro, BV yang rendah, tetapi juga mampu mempertahankan struktur tersebut jika mengalami pembasahan tiba-tiba dan serangan energi luar seperti energi kinetic pukulan butir hujan. Oleh sebab itu, pemeliharaan sifat fisika tanah tetap pada kondisi prima perlu dilakukan untuk menghindari terjadinya bencana alam.

Sub DAS Sumpur merupakan salah satu daerah aliran sungai yang terletak di Kabupaten Tanah Datar Sumatra Barat. Daerah ini dialiri oleh sebuah sungai yang bernama Sungai Aie Batanang, yang airnya mengalir dan bermuara ke danau Singkarak. Danau Singkarak merupakan sebuah danau yang sangat penting artinya bagi penyediaan energi listrik di Sumatra Barat. Sebagian besar air danau itu dimanfaatkan oleh proyek vital PLTA Singkarak dan pompanisasi Sumani. Dengan demikian sumberdaya tanah dan air dari sub DAS ini perlu dilestarikan. Penelitian ini bertujuan untuk mengkaji sifat fisika tanah pada 4 satuan lahan di Sub-Sub DAS Aie Batanang, Kabupaten Tanah Datar.

\section{BAHAN DAN METODA}

Penelitian ini dilakukan di sub-sub DAS Aie Batanang, Sub DAS Sumpur, DAS Ombilin atau DAS Kuantan yang merupakan salah satu DAS yang sudah kritis dan harus mendapatkan prioritas utama untuk ditanggulangi permasalahannya.

Tabel 1. Satuan lahan daerah penelitian dan luasnya

\begin{tabular}{c|cccc}
\hline \multirow{2}{*}{ No. Satuan Lahan } & $\begin{array}{c}\text { Slope } \\
(\%)\end{array}$ & Penggunaan Lahan & \multicolumn{2}{c}{ Luas } \\
\hline I & $8-15 \%$ & Kebun Campuran & 568.6 & 26.57 \\
\hline II & $8-15 \%$ & Hutan & 585.10 & 27.34 \\
\hline III & $15-25 \%$ & Hutan & 727.90 & 34.01 \\
\hline IV & $25-45 \%$ & Hutan & 258.40 & 12.07 \\
\hline
\end{tabular}


Berdasarkan peta jenis tanah, pada daerah studi hanya ditemui saju jenis tanah yaitu ordo Inceptisol dan sub ordo Dystropept. Penelitian berlangsung pada bulan Agusutus sampai Desember 2006. Pada penelitin ini diawali dengan mengambil contoh tanah utuh dan terganggu pada masing-masing satuan lahan di lapangan, kemudian dilanjutkan dengan analisis sifat fisika tanah di laboratorium ilmu tanah Fakultas Pertanian Universitas Andalas Padang.

Penelitian ini menggunakan metoda survai dengan pengambilan sample tanah berdasarkan satuan lahan atau purposive random sampling. Satuan lahan diperoleh dari overlay penggunaan lahan dan peta lereng. Dari hasil overlay diperoleh 4 satuan lahan (Tabel 1) pada daerah penelitian.

Contoh tanah terganggu yang dibawa ke laboratorium dikering-anginkan dan dihaluskan sesuai dengan kebutuhan analisis, yaitu $2 \mathrm{~mm}$ untuk analisis tekstur dan $0.5 \mathrm{~mm}$ untuk analisis bahan organik. Contoh tanah utuh dalam ring sample digunakan untuk analisis BV, TRP , dan permeabilitas tanah. Analisis tekstur dilakukan dengan metoda pipet dan ayakan berdasarkan hukum Stokes, analisis bahan organik dengan metoda Walkley dan Black, analisis BV dan TRP berdasarkan Gravimetri, dan permeabilitas dengan metoda De Boodt berdasarkan hukum Darcy.

\section{HASIL DAN PEMBAHASAN}

Keadaan Daerah Penelitian

Daerah penelitian merupakan daerah aliran sungai hulu dari Sub DAS Sumpur DAS Batang Kuantan (Inderagiri). Secara adminitrasi DAS ini terletak pada Kecamatan X Koto Kabupaten Tanah Datar. Daerah studi terletak pada daerah bertopografi beragam mulai dari daerah berombak sampai daerah berbukit dan bergunung, kemiringan lahan berkisar dari 8- $45 \%$ (Tabel 2). Penggunaan lahan terdiri sebagian besar hutan dan sebagian kecil adalah kebun campuran (Tabel 3).

Berdasarkan Tabel 2 dapat dinyatakan bahwa daerah penelitian sudah termasuk daerah yang harus dilindungi karena tanahnya tidak ada yang datar, dan hampir separoh $(46.11 \%)$ bentuk lahannya termasuk berlereng agak curam sampai curam. Kondisi demikian sangat riskan terjadinya degradasi lahan, kemunduran kesuburan tanah, terutama kesuburan fisika tanah, jika daerah tersebut dibuka untuk lahan pertanian. Pembukaan lahan untuk areal pertanian, terutama tanaman pangan dan tanaman semusim lainnya, membutuhkan pengolahan tanah yang intensif yang merupakan penyebab utama kemunduran sifat fisika tanah. Hal ini disebabkan karena pengolahan tanah akan mengintensifkan oksidasi bahan organik, sehingga fungsinya dalam membentuk dan mestabilkan aggregate tanah tidak bias diharapkan.

Tabel 2. Luas daerah studi pada masing-masing kelas kemiringan lahan

\begin{tabular}{|c|l|r|r|}
\hline \multirow{2}{*}{$\begin{array}{l}\text { Kemringan } \\
\text { Lahan }(\%)\end{array}$} & \multirow{2}{*}{ Bentuk Lahan } & \multicolumn{2}{|c|}{ Luas } \\
\cline { 2 - 4 } & & $(\mathrm{Ha})$ & $(\%)$ \\
\hline $0-3$ & Datar & 0.00 & 0.00 \\
\hline $3-8$ & Berombak & 0.00 & 0.00 \\
\hline $8-15$ & Bergelombang & 1153.00 & 53.89 \\
\hline $15-25$ & Agak Curam & 727.90 & 34.10 \\
\hline $25-45$ & Curam & 258.40 & 12.01 \\
\hline$>45$ & Sangat Curam & 0.00 & 0.00 \\
\hline Jumlah & & 2140.00 & 100.00 \\
\hline
\end{tabular}


Tabel 3. Jenis dan luas penggunaan lahan daerah studi

\begin{tabular}{|l|l|r|c|}
\hline \multirow{2}{*}{ No } & \multirow{2}{*}{ Penggunaan Lahan } & \multicolumn{2}{|c|}{ Luas } \\
\cline { 3 - 4 } & & $(\mathrm{Ha})$ & $(\%)$ \\
\hline 1 & Hutan & 1571.4 & 73.43 \\
\hline 2 & Kebun Campuran & 568.6 & 26.57 \\
\hline & Jumlah & 2140.0 & 100.00 \\
\hline
\end{tabular}

Dari Tabel 3 dapat dilihat bahwa pada umumnya penggunaan lahan dijumpai pada daerah studi adalah hutan. Hanya sekitar $26.57 \%$ daerah penelitian yang sudah dibuka dan dijadikan kebun campuran, yaitu area yang relative agak datar dibanding area lainnya, yaitu daerah dengan kemiringan 8$15 \%$. Berdasarkan jenis penggunaan lahan, kebun campuran dan hutan, seharusnya tanah daerah penelitian ini masih mempunyai tingkat kesuburan fisika yang baik. Hal ini disebabkan karena hutan tidak pernah diolah tanahnya. Pengolahan tanah yang intensif sering menyebabkan terdegradasinya sifat fisika tanah. Seperti lahan hutan, kebun campuran biasanya juga tidak diolah kecuali bila ditanami atau ditumpang-sarikan dengan tanaman semusim. Namun, setidaknya kebun campuran mempunyai tanaman tua yang kanopinya mampu mereduksi energy kinetic butir hujan, dan akarnya mampu melewatkan air dari permukaan ke dalam tanah, sehingga tanah terlindung dari proses erosi dan degradasi lahan.

\section{Sifat Fisika Tanah}

Hasil analisis beberapa sifat fisika tanah daerah penelitian ditampilkan pada Tabel 4. Tanah penelitian pada lereng 8$15 \%$ mempunyai kelas tekstur yang lebih kasar (liat berdebu) dibanding lahan dengan kemiringan $15-45 \%$ (liat). Hal ini menunjukkan bahwa tanah di daerah ini sedang dan sudah mengalami pelapukan dan perkembangan profil. Tekstur tanah yang halus dengan kandungan debu yang tinggi serta kandungan bahan organik yang rendah sangat rawan terdegradasi bila diolah intensif. Oleh sebab itu, tanah yang demikian hanya disarankan untuk dikonservasi atau dihutankan saja.
Srtuktur tanah pada lahan penelitian berbeda degan perbedaan penggunaan lahan. Lahan kebun campuran mempunyai struktur tanah gumpal bersudut, sedangkan lahan hutan dengan kemiringan yang sama mempunyai struktur granular. Penggunaan lahan hutan pada semua kelas lereng mempunyai struktur tanah yang sama, yaitu granular. Struktur gumpal pada kebun campuran bias disebabkan oleh tekanan yang terjadi pada permukaan lahan saat pembukaan lahan. Di samping itu juga mungkin disebabkan oleh kegiatan manusia dalam memanfaatkan, termasuk menanam dan memanen hasil, lahan tersebut. Pemanfaatan lahan oleh manusia untuk kehidupannya sering menyebabkan perubahan sifat fisika tanah, salah satu sifat fisika tanah yang paling dinamis yaitu struktur tanah. Struktur tanah akan hancur atau lebih padat jika dilakukan pengolahan terus menerus secara intensif dan juga akibat tekanan beban diatasnya seperti injakan binatang, mesin pertanian dan sebagainya. Selanjutnya, lahan hutan yang juga tidak pernah dibuka akan mempunyai sumber bahan organik yang lebih tinggi dan permanen dibanding kebun campuran. Bahan organik sangat berperan dalam proses pembentukan dan penstabilan aggregate tanah.

Bahan organik tanah bervariasi dari sangat rendah sampai sedang pada daerah penelitian. Kandungan bahan organik tanah paling rendah terdapat pada satuan lahan IV, hutan dengan kemiringan $25-45 \%$. Lalu diikuti oleh satuan lahan I, kebun campuran dengan kemiringan $8-15 \%$. Lahan hutan dengan kemiringan $8-25 \%$ (satuan lahan III dan IV) mempunyai kandungan bahan organik tertinggi diantaranya, yaitu termasuk kriteria sedang. Kalau dilihat pada penggunaan lahan hutan, 


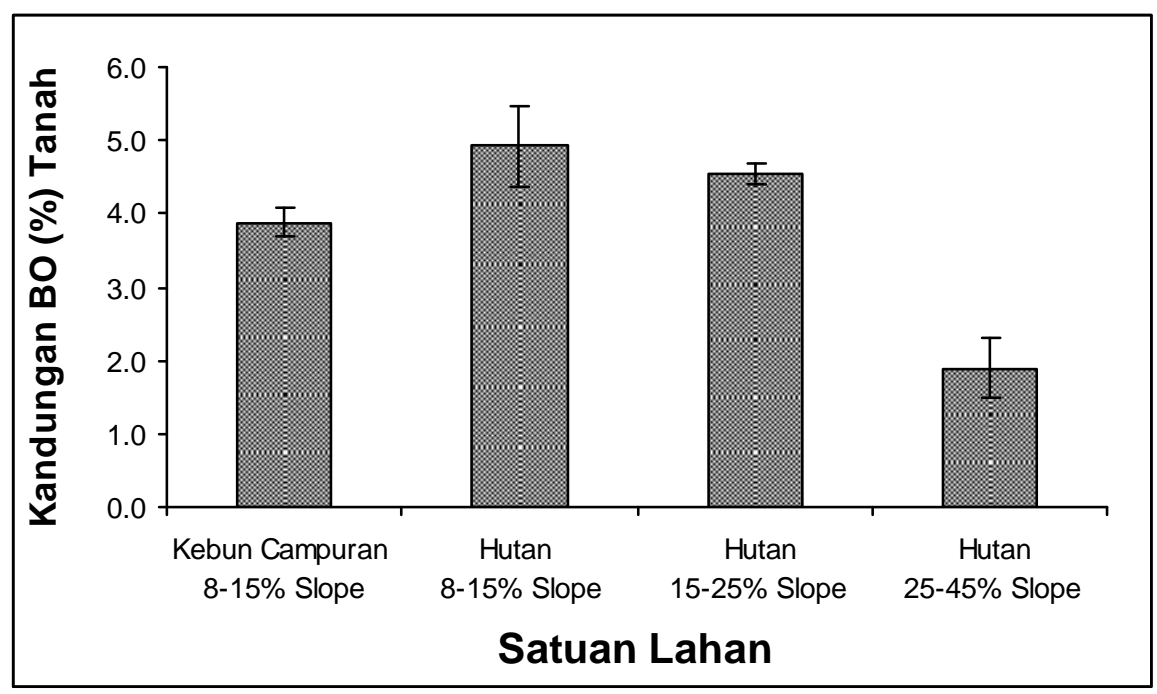

Gambar 1. Kandungan bahan organik tanah pada setiap satuan lahan

terdapat kecendrungan penurunan kandungan bahan organik tanah dengan peningkatan persentase lereng. Hal ini mungkin disebabkan oleh proses pergerakan atau perpindahan bahan organik dari tempat jatuhnya ke tempat lain. Semakin curam suatu lahan semakin mudah dan banyak jumlah bahan organik yang berpindah ke tempat lain. Pada kemiringan yang sama, 8$15 \%$, kandungan bahan organik kebun campuran lebih rendah dari hutan. Hal ini disebabkan oleh sumber bahan organik tanah yang berbeda.

Kadar bahan organic Kebun Campuran bukan saja berbeda secara kriteria tetapi juga berbeda nyata secara statistic seperti ditampilkan pada Gambar 1. Bahan organic yang lebih rendah dan penggunaan lahan yang berbeda, walaupun tekstur tanah dan kelas lereng sama, mengakibatkan perbedaan struktur tanah.

Kandungan bahan organik tanah mempengaruhi nilai bobot volume tanah. Semakin tinggi kandungan bahan organik pada kelas tekstur yang sama semakin rendah bobot volume tanah dan semakin tinggi total ruang porinya. Pada kesemua satuan lahan pada daerah penelitian, BV tanah termasuk kriteria sedang, yaitu terletak antara 0.66-1.14 $\mathrm{gcm}^{-3}$. Hal ini didukung oleh tekstur tanah yang berliat, yang mempunyai berat persatuan volumenya lebih rendah dari tekstur kasar. Di samping itu, sesuai dengan ordo tanah yang termasuk Inceptisol yaitu yang sedang berkembang.

Total runag pori tanah yang tinggi tidak menjamin tinggi pula nilai permeabilitas tanah. Total runag pori tanah tertinggi terdapat pada satuan lahan hutan pada kemiringan $25-45 \%$, akan tetapi nilai permeabilitas tanah termasuk yang terkecil pada penggunaan lahan yang sama. Hal ini terlihat bahwa bahan organik tanah sangat menentukan tingkat permeabilitas tanah. Bahan organik yang tinggi mampu memeprtahankan stabilitas aggregate tanah, sehingga pori makro tanah tidak berkurang untuk melewatkan air ketika tanah dijenuhi. Akan tetapi, pada penggunaan lahan kebun campuran, walaupun bahan organik tanah lebih tinggi dibanding satuan lahan IV, laju permeabilitasnya lebih rendah. Hal ini dipengaruhi oleh struktur, BV dan TRP tanah. Tanah berstruktur gumpal bersudut agak susah melewatkan air dari granular. Tanah berstruktur granular akan mempunyai ruang pori makro yang lebih tinggi dari struktur gumpal bersudut. Di samping itu, tanah dengan penggunaan lahan kebun campuran lebih padat dibanding lahan hutan, dimana TRP tanah lebih kecil, sehingga tanah tidak mampu melewatkan air lebih banyak. 
Tabel 4. Hasil analisis sifat fisika tanah pada masing-masing satuan lahan

\begin{tabular}{|c|c|c|c|c|c|c|c|c|c|c|c|}
\hline & \multirow[t]{2}{*}{ Penggunaan Lahan } & \multirow[t]{2}{*}{ Slope $(\%)$} & \multicolumn{4}{|c|}{ Tekstur } & \multirow[t]{2}{*}{ Struktur } & \multirow{2}{*}{$\begin{array}{c}\mathrm{BV} \\
\left(\mathrm{gcm}^{-3}\right)\end{array}$} & \multirow{2}{*}{$\begin{array}{l}\text { TRP } \\
(\%)\end{array}$} & \multirow{2}{*}{$\begin{array}{c}\text { Bahan } \\
\text { Organik } \\
(\%)\end{array}$} & \multirow{2}{*}{$\begin{array}{l}\text { Permeabilitas } \\
\left(\mathrm{cm} \mathrm{jam}^{2}\right)\end{array}$} \\
\hline & & & $\begin{array}{c}\text { Pasir } \\
\%\end{array}$ & $\begin{array}{c}\text { Debu } \\
\%\end{array}$ & $\begin{array}{c}\text { Liat } \\
\%\end{array}$ & Kelas & & & & & \\
\hline 1 & Kebun Campuran & $8-15 \%$ & 5.98 & 41.21 & 52.81 & $\begin{array}{c}\text { Liat } \\
\text { Berdebu } \\
\end{array}$ & $\begin{array}{c}\text { Gumpal } \\
\text { Bersudut }\end{array}$ & 0.94 & 64.53 & 3.88 & 9.20 \\
\hline 2 & Hutan & $8-15 \%$ & 8.89 & 45.91 & 45.20 & $\begin{array}{c}\text { Liat } \\
\text { Berdebu }\end{array}$ & Granular & 0.85 & 67.92 & 4.92 & 19.72 \\
\hline 3 & Hutan & $15-25 \%$ & 8.55 & 37.56 & 53.89 & Liat & Granular & 0.87 & 67.17 & 4.54 & 20.38 \\
\hline 4 & Hutan & $25-45 \%$ & 4.52 & 37.90 & 57.58 & Liat & Granular & 0.77 & 70.94 & 1.89 & 16.18 \\
\hline
\end{tabular}




\section{KESIMPULAN DAN SARAN}

Berdasarkan hasil penelitian yang diperoleh dari sub-sub DAS AieBatanang dengan penggunaan lahan daerah studi adalah kebun campuran dan hutan, serta kemiringan lahannya umumnya berombak sampai agak curam, dapat disimpulkan bahwa :

a. Secara umum daerah penelitian masih mempunyai sifat fisika tanah yang baik

b. Tekstur tanah pada kemiringan 8$15 \%$ adalah liat berdebu dan pada kemiringan $15-45 \%$ liat

c. Bahan organik tanah kebun campuran termasuk kriteria sedang (3.88\%), sedangkan pada hutan 4.92 , 4.54, dan $1.89 \%$ untuk lereng 8-15, $15-25$, dan $25-45 \%$ secara berturutturut.

d. BV tanah kebun campuran tertinggi $\left(0.94 \mathrm{~g} \mathrm{~cm}^{-3}\right), \quad$ TRP terendah $(64.53 \%)$, dan permeabilitas

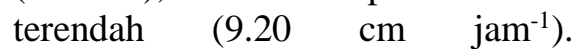
Sedangkan pada lahan hutan BV berkisar dari $0.77-0.87 \mathrm{gcm}^{-3}$, TRP dari 67.17-70.94\%, dan permeabilitas dari $16.18-20.38 \mathrm{~cm}$ $\mathrm{jam}^{-1}$.

Berdasarkan kesimpulan di atas dapat disarankan bahwa untuk menghindari terjadinya bahaya erosi dan degradasi lahan, daerah penelitian disarankan untuk tidak dibuka baik sebagai lahan pertanian maupun bagi lahan pemukiman dan sebagainya. Lahan kebun campuran tidak disarankan untuk tanaman semusim, tetapi cukup dengan tanaman tua yang tidak butuh pengolahan tanah.

U capan terima kasih kepada : Tim SP4 Jurusan Tanah yang telah memberikan dana dalam melaksanakan penelitian ini.

\section{DAFTAR PUSTAKA}

Mas ‘ud, A. F (1987) Perencanaan penelitian dan monitoring DAS secara terpadu, kemungkinan permasalahannya.
Prosiding Lokakarya Hasil Penelitian Hidrologi Dan Erosi Dalam Rangka Pengelolaan Daerah Aliran Sungai.Tanggal 8-10 Desember 1987. Batu Malang. Halaman 205-218. ,

Arsyad, S. (1989). Koservasi Tanah Dan Air. Penerbit IPB Bogor. 290 Halaman.

Balai Teknologi Pengelolaan DAS Solo. (1987). Kajian Pendugaan Erosi Berdasarkan Universal Soil Loss Equation ( USLE) Dengan Beberapa Metoda Penetapan Nilai Erosivitas Hujan. Prosiding Lokakarya Hasil Penelitian Hidrologi dan Erosi Dalam Rangka Pengelolaan Daerah Aliran Sungai . Batu Malang Tanggal 8-10 Desember 1987.

Balitbang Pertanian. (1986). Pedoman Pola Pembangunan Pertanian di Daerah Aliran Sungai (DAS). Bahan rapat Tanggal 21 Agustus 1986 di Balitbang Pertanian Departemen Pertanian Jakarta.

Baver, L.D. (1960). Soil Physics. Modern Asia Edition. John Wiley and Sons, New York.Charles E Tuttle Company.Tokyo. ,

Bols, P.L. (1978). The Iso-Erodent Map of Java and Madura. Belgian Technical Assistence Project ATA 105 and Soil Research Institute, Bogor, Indonesia.

BRLKT Wilayah II. (1985). Pola Rehabilitasi Lahan dan Konservasi Tanah Sub DAS Sumani. Direktorat Jenderal Reboisasi dan Rehabilitasi Lahan. Departemen Kehutanan.

Asdak, C.(1990). Hutan dan Perilaku Air. Lokakarya Pembangunan Kehutanan Yang Terlanjutkan. 7-8 Mai 1990.

Clark, E. H., Haverkamp, J.A., and Chapman, W. (1985). Eroding Soils; The Off Farm Impacts. The 
Conservation

Washington D C.

PSDAL UNPAD Bandung. Departemen Kehutanan dan Bakosurtanal. (1987). Pemetaan Bahaya Erosi (TBE) sub DAS Citarik dan Sekitarnya. Daerah Aliran Sungai Citarum. Kerjasama Departemen Kehutanan Bakosurtanal Jakarta.

Sutadipradja, E. (1987). Pokok-Pokok Pikiran Tentang Pengembangan Sistem Monitoring Tata Air Dalam Rangka Pengelolaan DAS di Indonesia. Prosiding Lokakarya Hasil Penelitian Hidrologi dan Erosi dalan rangka Pengelolaan DAS. Batu Malang Tanggal 8 - 10 Desember 1987.

Ditjen Tananaman Pangan. (1989). Repelita V Pertanian Tanaman Pangan. Departemen Pertanian Jakarta.

Ditjen Reboisasi dan Rehabilitasi Lahan. (1987). Pembukaan lahan, harga hidrologi dan erosi dalam rangka pengelolaan DAS. Departemen Kehutanan Jakarta.

Elliot, W. J., Foster, G. R. dan Elliot, A. V. (1991). Soil Erosion Processes, Impacts and Prediction. Soil Conservation Society. Ankeny.Iowa.

Hamilton, S. H. and King, P. N. (1988). Daerah Aliran Sungai Tropika. Terjemahan dari Tropical Forested Watershed oleh Ir. Krisnawati Suryanata dan Prof. Ir. Gombong Tjitrosoepomo. GajahMada University Press. Jokjakarta.

Haryanto, E T, Santoso, P., dan Syafrudin, A. (1990) Hidrologi dan Erosi.Lokakarya Pembangunan Kehutanan Terlanjutkan . Bandung, 7 - 8 Mai 1990.

Lal, R. and Russell, E. W. (1981). Tropical Agricultural Hydrology.
Watershed Management and Land Use. John Wiley and Sons Inc. New York.

Russel, E W (1981) Role of watershed management for arable land use in the tropics. In Tropical Agricultural Hydrology . Edited by R Lal and E W Russell. John Wiley and Sons. New York. ,

Schwab, G. O., Frevert, R. K., Edminster, T. W., and Barnes, K. K. (1981). Soil and Water Conservation Engineering. John Wiley and Sons. New York.

Sidik, H. T., Suwardjo, H., dan Barus, A. (1987). Pengaruh Cara Pembukaan Lahan Dan Teras Gulud Terhadap Aliran Permukaan , Erosi, dan Ketahanan Tanah Pada Suatu Daerah Tampung. PPT Bogor.

Soerjono, R. (1987). Peran Serta Hutan Dalam Menambah Air Dalam Pengelolaan Daerah Aliran Sungai. Prosiding Lokakarya Hasil Penelitian Hidrologi dan Erosi dalam Pengembangan Daerah Aliran Sungai (DAS). Batu Malang. Tanggal 8 - 10 Desember 1987. halaman 5 - 12 .

Soewarno. (1991). Hidrologi, Pengukuran dan Pengelolaan Data Aliran Sungai (Hidrometri). Penerbit Nova Bandung. .

Soil Survey Staff. (1990). Keys to Soil Taxonomy. SMSS. SCS USDA. Washington, DC.

Sukmana, S dan Suwardjo, H. (1980). Aliran Permukaan Dan Erosi Pada Tanaman Pertanian Tanaman Semusim. Makalah dalam Seminar Hidrologi dalam pengembangan pengelolaan DAS. Dalam Rangka Pekan Lingkungan Hidup. Surakarta tanggal 6 - 7 Juni 1980. 
Suwardjo dan Sinukaban, N. (1986). Masalah Erosi dan Kesuburan Tanah di Lahan Kering Podzolik Merah Kuning di Indonesia. Lokakarya Usahatani Koservasi di lahan alangalang Podzolik Merah Kuning. Palembang, 11 - 13 Februari 1986.

Syarbaini, M. 1987. Karakteristik Sub DAS Arau I Kotamadya Padang. Tesis Fakultas Pasca Sarjana IPB. Bogor. 125 hal.
Wischmeier, W. H. and Smith, D. D. (1978). Predicting Rainfall Erosion Losses. A Guide to Conservation Planning. Supersedes Agriculture Handbook no 282.

Young, A. (1989). Agroforestry for Soil Conservation. $\mathrm{CAB}$ International. International Council Research in Agroforestry. BPCC Whetons, Exerter. 


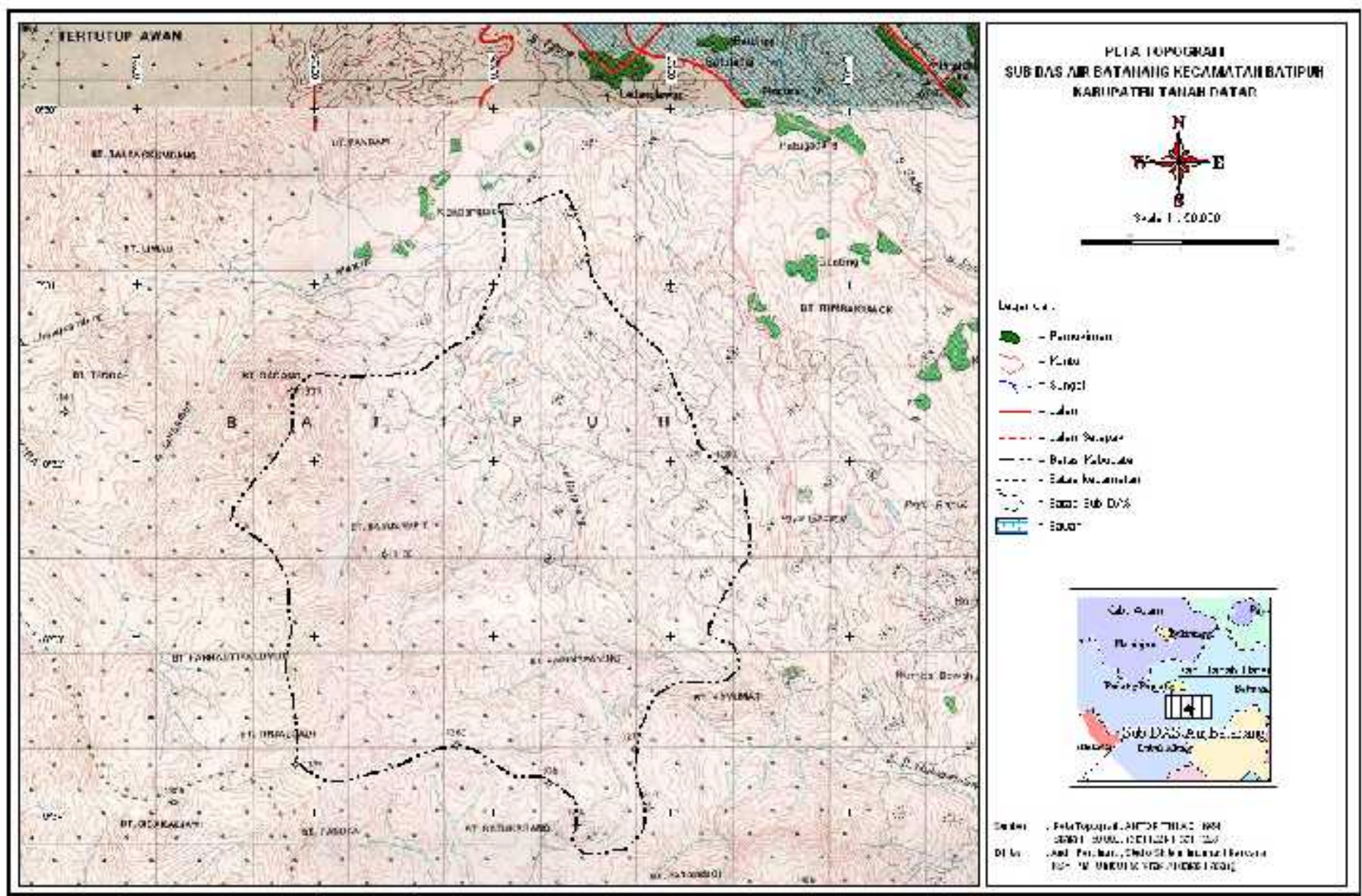

Lampiran 1. Peta Topografi Sub DAS Aie Batanang Kecamatan Batipuh Kabupaten Tanah Datar 